\title{
ENVIRONMENTAL POLICY OF THE EU: INSIGHTS FOR FURTHER DEVELOPMENT
}

\author{
Marta Vovk*, Boris Dziura**, Martin Grešš $* *$ \\ * University of Economics in Bratislava, Faculty of National Economy, Dolnozemská cesta 1, \\ 85235 Bratislava, Slovakia, marta.brawin@gmail.com \\ ** University of Economics in Bratislava, Faculty of International Relations, Dolnozemská cesta 1, \\ 85235 Bratislava, Slovakia, boris.dziura@euba.sk, martin.gress@euba.sk
}

\begin{abstract}
Environmental policy of the EU: insights for further development
The article focuses on researching the cost-effectiveness of environmental policy in the EU and the relationship between the diversity of the system of environmental policy instruments and the economic development of the EU. The cost-effectiveness of environmental policy in the EU is based on the analysis of ex-ante CEAs (CostEffectiveness Assessment), price of activity, use of market-based instruments, the CEA as part of a policy/directive and environmental expenditures. Cost-effectiveness is mainly influenced by policy instrument choice and operational efficiency. The analysis of environmental expenditures in the EU countries as one of the main focuses of cost-effectiveness has shown that, despite increasing standards of environmental regulation, environmental protection expenditures do not place a heavy burden on the economies that is explained by the increased efficiency of sectors in responding to more stringent environmental legislation. We have tested the hypothesis that the system of environmental instruments applied in the developed EU countries is more diverse than in developing and transition economies since developed countries have long established laws and formal governmental structures to address their serious environmental problems. Our finding is that the degree of variety of environmental policy instruments among the EU members is dependent, not only on production development and actual environmental issues, but also on other factors of development, as in not all the countries with a high number of production enterprises is the system of environmental policy instruments diverse. Only in Austria, Belgium, Denmark, Finland, France, Germany, Ireland, Luxembourg, Netherlands, Sweden and the United Kingdom is the system of environmental policy instruments the most diverse. These countries joined the EU much earlier than many other member states, thus, they have a sounder institutional framework.
\end{abstract}

Key words: envir onmental policy, cost-effectiveness, cluster analysis, the EU

\section{INTRODUCTION}

There are at least three reasons for positioning an inquiry on the costeffectiveness of environmental policy in the EU and the relationship between the diversity of the system of environmental policy instruments and the economic development of the EU, notably: 1) the cost-effectiveness of the implementation of environmental policy remains one of the most discussed problems, which is believed to impede effectiveness, efficiency and added value in the EU; 2) evidence of the positive influence of environmental policy on the innovation process; 3) an increasing role of voluntary approaches and environmental R\&D in mitigating environmental impacts and promoting eco-innovations.

Nevertheless there are many factors affecting the cost-effectiveness of environmental policy, it should be noted that the geographical factor is among the important ones as to a large extent it identifies the country's environmental conditions. Dealing with the same environmental problems in different countries does not sup- 
pose the same costs of the elimination of these problems, but not due to higher environmental standards in certain countries than in others, but because of, for example, the absence of strong airflows, which are vital for the dispersion of pollutants in the atmosphere, or weak water flows which prevent water purification. Thus, when analyzing cost-effectiveness and the stringency of environmental policy based only on the data on the costs of compliance with environmental policy, it should be taken into account that increasing environmental costs should not always be consi-dered as a pure indicator of the cost-effectiveness and stringency of environmental policy. It rather means that in order to achieve the same environmental standards some countries have to spend more financial sources than others.

One of the biggest difficulties in analyzing the cost-effectiveness of environmental policy is identifying the proper approach to define it. Two main approaches could be outlined: one, which complies with the equimarginality principle of costeffectiveness and the second one based on the documents of international organizations (the European Commission, the Intergovernmental Panel on Climate Change, the International Energy Agency) defining cost-effectiveness as "the lowest costs of support" (del Río and Cerdá 2014). Current research is based mainly on the documents of the European Commission.

Many studies are devoted to identifying cost-effective combinations of environmental measures to achieve reduction in pollution levels (Balana et al. 2015), thermal targets (Tubelo et al. 2018), renewable targets for 2022 (Shrimali et al. 2016) or other targets. Some of the studies recommend focusing on education and training for increasing the cost-effectiveness of environmental programmes (Yushchenko and Patel 2017).

A large number of research deals with the influence of different environmental policy instruments on the green innovation. Findings show that the market-based instruments have more significant positive effects on green product innovation than command-and-control ones (Liao 2018). At the same time other results show that environmental policy may negatively affect green product innovation. Controlling the demand-side effect, regulations and taxes negatively impact green product innovation, thus, if regulation and taxes do not trigger additional demand, they decrease the propensity to innovate. Subsidies and (partly) voluntary agreements are positively related with green product innovation (Stucki et al. 2018).

Many studies have made a considerable contribution to researching the role of a voluntary approach (Khanna and Brouhle 2013, Ball et al. 2017 and Li 2017) and environmental R\&D investments in mitigating environmental impacts and promoting eco-innovations (Yakita and Yamauchi 2011 and Ghisetti and Pontoni 2015). The research findings show that these approaches can promote eco-innovation whilst simultaneously protecting the natural environment. Research on ecoinnovations in the field of the construction industry in Poland shows the benefits of cooperation like knowledge exchange, experience and technology joint offers reducing business operation costs while improving efficiency through synergy (Stasiak-Betlejewska and Potkány 2015). The followers of Porter's theory (Porter and van der Linde 1995) continue to study the effects of environmental policies on the economic development of countries and have come to the conclusion that environmental policy positively influences patent activity (Singh et al. 2017), induces more R\&D (Yang et al. 2012), and leads to a significant relationship between the degree of support for environmental projects and the economic development of the regions (Adamišin et al. 2018). 
This research analyses the factors influencing the cost-effectiveness of environmental policy in the EU countries and identifies the dynamics of environmental expenditures as one of the main focuses of cost-effectiveness in general government, industry and manufacturing during $2004-2012$. The current study contributes to a better understanding of the differences in environmental policy design across member states and the different degree of the effectiveness of environmental policy among member states.

The diversity of the system of environmental policy instruments is important as the more sources are attracted to fight with pollution, the lower their level will be. The diversity of policy instruments does not necessarily mean that the more diverse, the more stringent the policy is in particular, the more cost-effective it is. At the same time in many cases the application of such instruments, as an educational approach or voluntary approach does not bring much yields, but they often serve as tools, which increase public support for more stringent (and effective) policies (Burton at al 2017). And even if they do not change polluting behaviour, the economic agents and population are informed about the consequences of not environmentally-agreed behaviour.

Based on prior evidence suggesting the influential role of economic and institutional determinants when pointing out the successes and failures of environmental policies adopted and the finding that economic variables play a most important role in the diffusion process of environmental policy, we hypothesize that the degree of diversity of the system of environmental policy instruments in the EU is dependent on the degree of the economic development of the countries (Arbolino et al. 2018).

\section{THE COST-EFFECTIVENESS OF ENVIRONMENTAL POLICY IN THE EU}

In the tabs. $1-4$ the factors and the main characteristics of the costeffectiveness of environmental policy in the EU are presented.

Tab. 1. Factors that define the degree of cost-effectiveness in policy implementation

\begin{tabular}{ll}
\hline Policy factors & Natural or policy external factors \\
\hline Sector organization (ownership, financial incentives etc.) & Population size, age composition and density \\
Choice (and design) of policy instrument & Economic structure and activity \\
Choice of technology & Price and cost levels \\
Operational Efficiency & Industry composition, technological level \\
& The existing environmental quality \\
& Landscape characteristics \\
& Soil conditions \\
& Climate characteristics \\
& Social and cultural traditions \\
& Administrative traditions \\
\hline
\end{tabular}

Source: European Commission (2009). 
It is possible to conclude from the tabs. $1-4$ that whatever the primary conditions, the cost-effectiveness of environmental policy in the EU is based on the analysis of environmental expenditures and is mostly impacted by policy instrument choice and operational efficiency. In this context the use of market-based instruments is crucial. In order to justify an environmental policy as a factor that can turn into an additional factor of the economic growth of a country, the costs of compliance with environmental policies should be optimized to avoid harmful influence on enterprises.

Tab. 2. Overview of the impact of factors influencing cost-effectiveness (from low impact to medium and high impact)

\begin{tabular}{lllll}
\hline Area & $\begin{array}{l}\text { Organization } \\
\text { of sector }\end{array}$ & $\begin{array}{l}\text { Policy instrument } \\
\text { choice }\end{array}$ & $\begin{array}{l}\text { Operational efficiency Comments } \\
\text { including incentives to } \\
\text { optimize }\end{array}$ \\
\hline Water & Low & High & High & $\begin{array}{l}\text { More incentive pricing and benchmarking } \\
\text { of operations could improve CE }\end{array}$ \\
Waste & Medium/high & Medium & High & $\begin{array}{l}\text { Organizational setup of the sector and the } \\
\text { benchmarking of individual management } \\
\text { operations could improve CE }\end{array}$ \\
Air & Low & High & Low & $\begin{array}{l}\text { Increased use of MBI is likely to offer some } \\
\text { improvement potential }\end{array}$ \\
\hline
\end{tabular}

CE - cost effectiveness; MBI - market-based instruments

Source: European Commission (2009).

Tab. 3. Indicator assessment of cost-effectiveness status by environmental area

\begin{tabular}{ll}
\hline Area & Overall level of expenditure \\
\hline Water & High \\
Waste & High \\
Air & Medium \\
Integrated & Low (IPPC: Medium) \\
Climate change & Possibly high in the future \\
Bio-diversity & Low/medium \\
Chemicals & Low \\
Cross-cutting (administrative activities: & Low/medium \\
monitoring, permitting, inspection etc) & \\
\hline
\end{tabular}

IPPC - Integrated Pollution Prevention and Control

Source: European Commission (2009). 
Tab. 4. Indicators of cost-effectiveness differences across member states

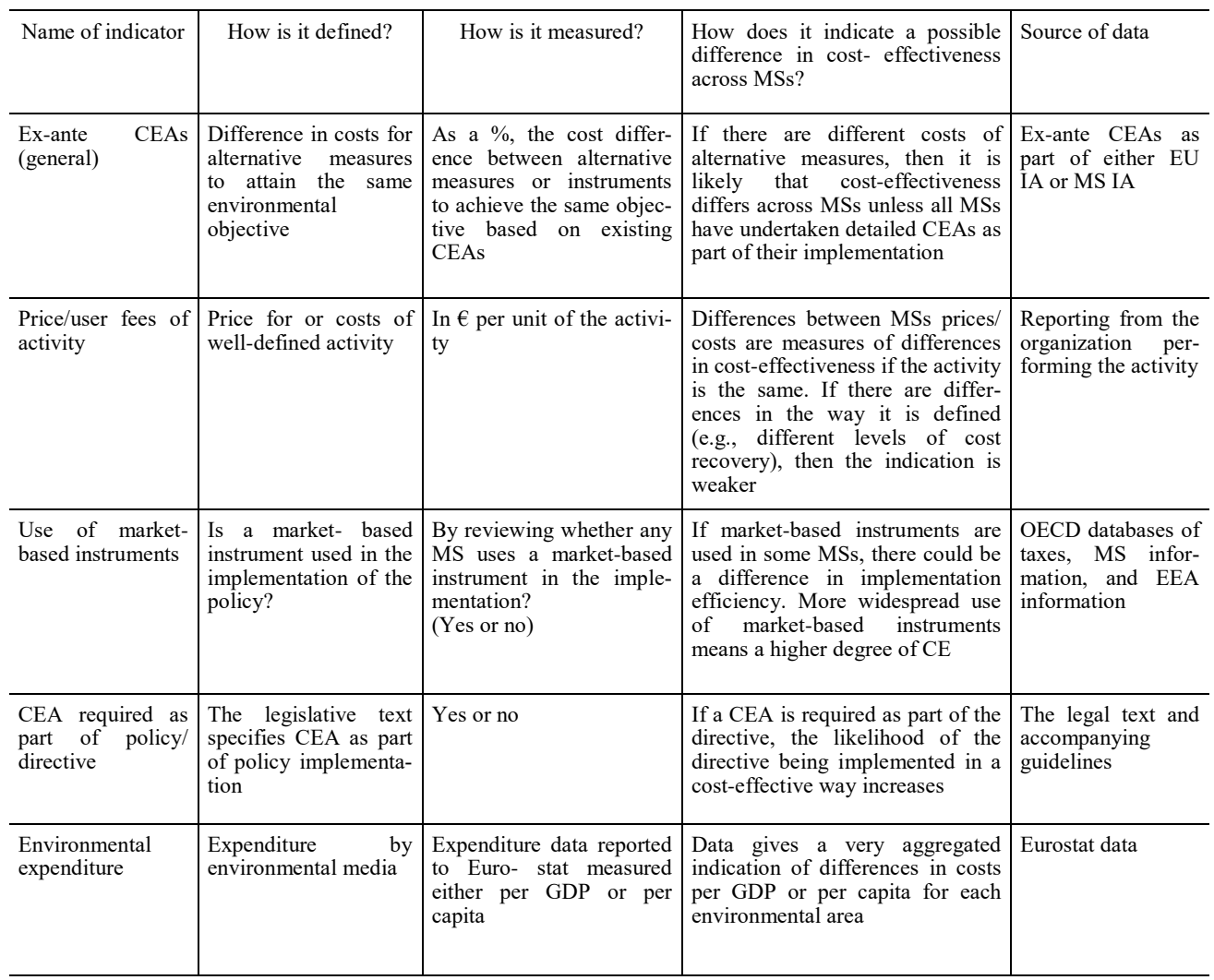

MS - member state; IA - Impact Assessment; EEA - European Environment Agency

Source: European Commission (2009).

\section{ENVIRONMENTAL EXPENDITURES AND INFRINGEMENTS IN THE EU}

\section{Environmental protection expenditures}

When talking about macro level figures it should be mentioned that according to the last available statistics the environmental protection expenditures in the EU countries account for not more than $1.38 \%$ of GDP. On average (Fig. 1) they are about $0.67 \%$ of GDP and during the period between 2004 and 2012 they increased only by $0.05 \%$. Environmental protection expenditures in the EU industry sector except for construction, sewerage, waste management and remediation activities (Fig. 2) were $0.40 \%$ of GDP and in manufacturing $0.26 \%$ in 2012 (Fig. 3). According to the European Commission environmental protection expenditures are determined as "the sum of capital and current expenditure on environmental protection activities". The latter includes the use "of manufacturing techniques and practices, equipment, labour, information networks or products". The main goal of environmental protection activities is to collect, treat, reduce, prevent or eliminate pollutants and pollution or any other degradation of the environment resulting from the 
activity of the business (Ollson et al. 2005). At the same time environmental protection expenditures may relate to activities that generate marketable by-products or results in savings or are financed by subsidies or capital allowances. Depreciation allowances for environmental equipment and transfers such as payments of taxes, fees or charges by the reporting unit are excluded (European Commission 2016a).

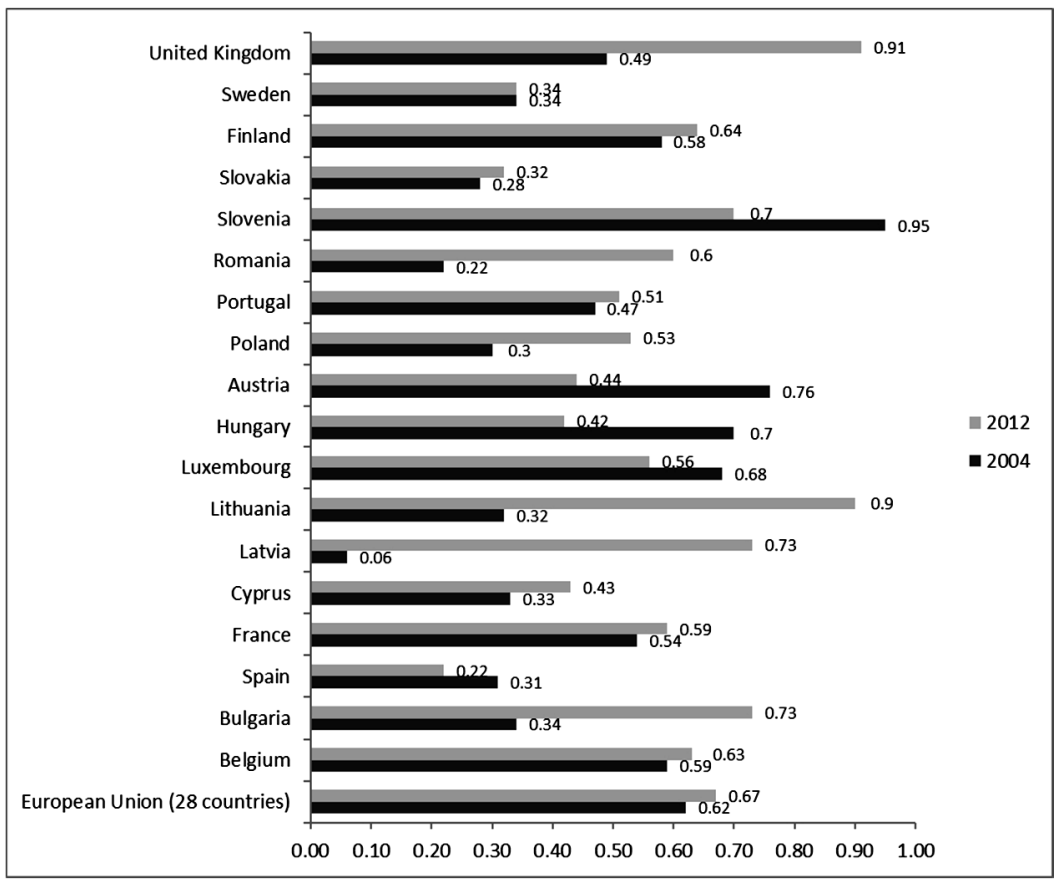

Fig. 1. Environmental protection expenditures of general government, total environmental protection activities ( $\%$ of GDP)

Source: Authors, based on the data from European Commission (2016a).

Total environmental protection expenditures are divided according to the property sectors into:

- Public sector - government institutions (central public administration, regional and local governments, public organizations and institutions mainly classified in NACE, Rev.1);

- Business sector - commercial enterprises, financial and insurance institutions, non-commercial institutions (all activities except NACE 75);

- Producers specialized in environmental protection (NACE 37 and 90) whose main activity is providing services for environment protection, mainly waste collection disposal and sewage treatment;

- Household sector - there is no clear distribution into investment and current expenditure in this sector; the specificity of household activities combines all the types of expenditure together (Broniewicz 2011). 


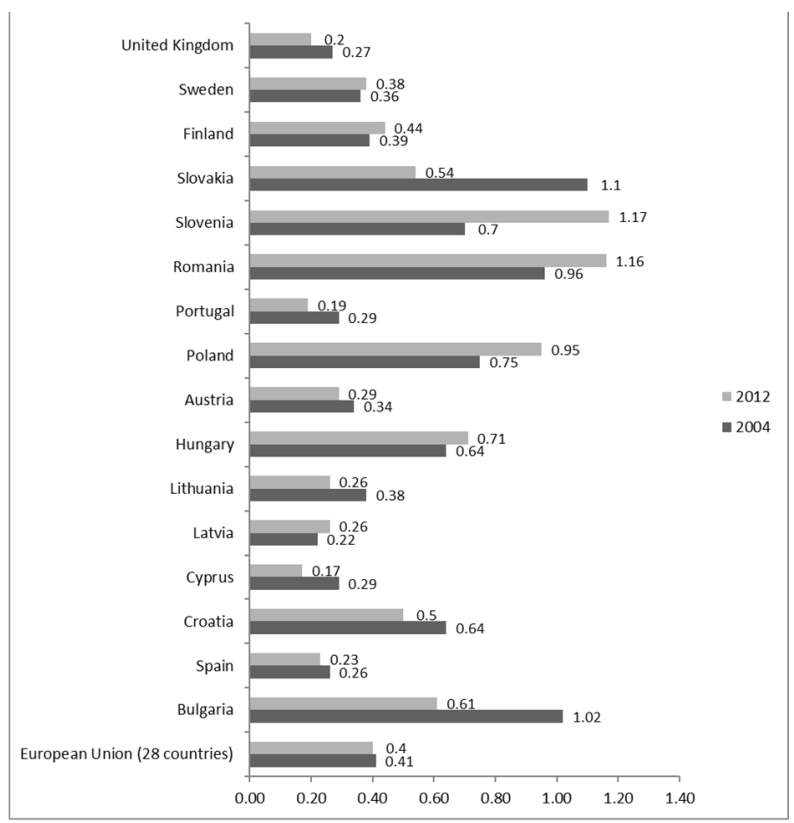

Fig. 2. Environmental protection expenditures, total environmental protection activities, industry - except for construction, sewerage, waste management and remediation activities) (\% of GDP)

Source: Authors, based on the data from the European Commission (2016b).

Thus, despite increasing standards of environmental regulation, environmental protection expenditures do not place a heavy burden on the economies. According to European Commission (2015) research, it is explained by the increased efficiency of sectors in responding to more stringent environmental legislation. However, at the same time in the research has been highlighted that among sectors and member states cost-effectiveness varies considerably. It is explained mainly by several reasons. Due to the introduction and implementation of new regulations there are peaks in environmental investments, which often lead to a provisional increase in environmental expenditures. It should be mentioned that in "new" member states environmental expenditures are frequently above the EU average. The reason for this is that "new" member states have been investing in environmental protection for a relatively short time, in order to comply with EU regulations. The second reason is that in the "new" member states the scale of the firms is often smaller than in "old" ones. Operational and investment expenditures have a tendency to diminish as a consequence of technological progress. Technological progress can also be demonstrated by the growth of the share of integrated technologies. It has been reported by the European Commission (2015) that a share of total environmental investments has increased from $0-15 \%$ in 1995 to $40-50 \%$ in 2012 in all sectors explored except for quarrying and mining. Relatively high environmental expenditures have a favorable impact on innovative solutions that subsequently diminish those expenditures. 


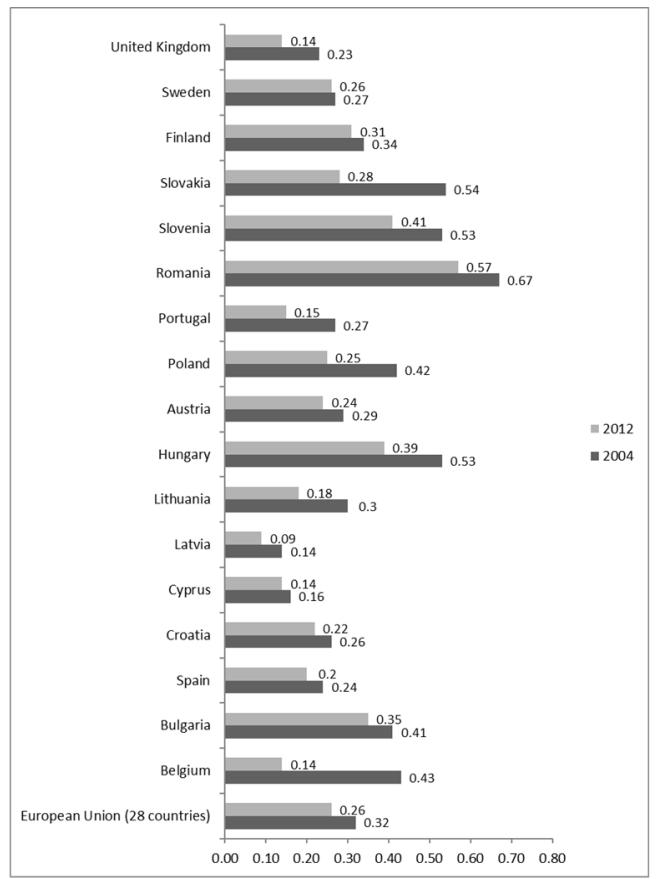

Fig. 3. Environmental protection expenditures, total environmental protection activities, manufacturing ( $\%$ of GDP)

Source: Authors, based on the data from the European Commission (2016c).

\section{Environmental infringements in the EU}

When considering statistics on environmental infringements in the EU (Figs. 4 -6), we can conclude that during 2007 - 2017 the overall number of environmental infringements in the region decreased by $47 \%$ and most of them are observed in the water and waste sector, which is characterized by the highest environmental expenditures. Spain and Greece have the highest numbers of environmental infringements according to the latest available data.

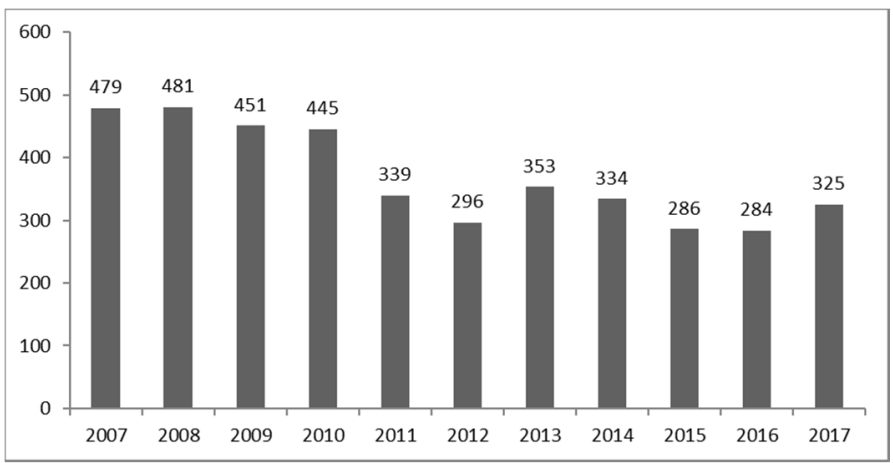

Fig. 4. Open Directorate-General for Environment Infringements Source: European Commission (2018a). 


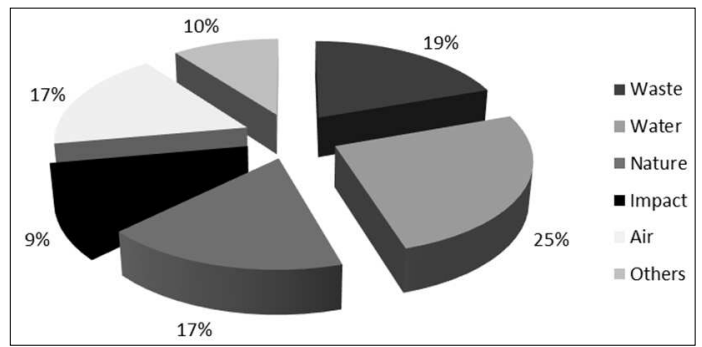

Fig. 5. Infringements by environmental sector, 2017

Source: European Commission (2018b).

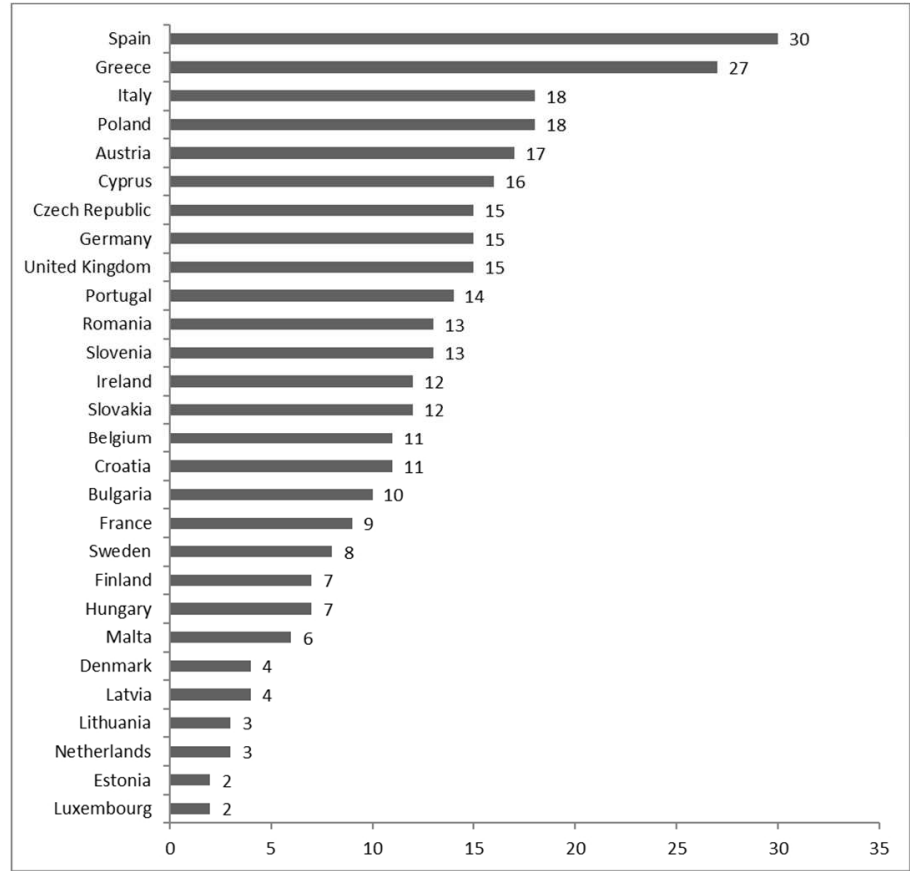

Fig. 6. Infringements per Member State Source: European Commission (2018c).

\section{RELATIONSHIP BETWEEN THE DIVERSITY OF THE SYSTEM OF ENVIRONMENTAL POLICY INSTRUMENTS AND ECONOMIC DEVELOPMENT OF THE EU COUNTRIES}

\section{Hypothesis}

In this section we have tested the hypothesis that the system of environmental instruments applied in the developed EU countries is more diverse than in developing and transition economies since developed countries have long established laws and formal governmental structures to address their serious environmental problems. 


\section{Data and methodology}

In the current research we have used cluster analysis to identify groups of the EU countries with similar competitive advantages and environmental performance. The clustering of data is done by using the Ward method. This method is effective because it uses the methods of dispersion analysis to estimate the distances between clusters. This method minimizes the sum of squares for any two (hypothetical) clusters, which can be formed at each step. This method intends to create small clusters (Ward 1963). This property is also important for our research, since we have 28 countries, which are characterized by different levels of development and competitiveness. Thus, the countries can be combined into classes (clusters) according to similar features. Then each cluster has been analyzed from the point of view of the practice of the use of different instruments of environmental policy.

The method of cluster analysis does not give an opportunity to identify the level of the development or competitiveness of the countries, but it gives an opportunity to determine the common features of the countries and in which way they can be grouped. Conducting cluster analysis contributes to an understanding of relationships between different indicators of the development of the EU members.

The indicators, included in the cluster analysis, are presented in Table 5.

\section{Tab. 5. Indicators for cluster analysis (the last available data)}

\begin{tabular}{llll}
\hline Indicator & Unit of measurement & Source \\
\hline $\mathrm{P}$ & Environmental Performance Index & Index & (Yale University 2018) \\
$\mathrm{T}$ & Institutions & Index & \\
$\mathrm{T}$ & Infrastructure & Index & \\
$\mathrm{R}$ & Macroeconomic environment & Index & \\
$\mathrm{T}$ & Health and primary education & Index & \\
$\mathrm{T}$ & Higher education and training & Index & \\
$\mathrm{R}$ & Goods market efficiency & Index & \\
$\mathrm{R}$ & Labor market efficiency & Index & (Schwab et al. 2017) \\
$\mathrm{R}$ & Financial market development & Index & \\
$\mathrm{P}$ & Technological readiness & Index & \\
$\mathrm{R}$ & Market size & Index & \\
$\mathrm{R}$ & Business sophistication & Index & \\
$\mathrm{P}$ & Innovation & Index & \\
$\mathrm{P}$ & Global Talent Index & Index & \\
\hline
\end{tabular}

* $\mathrm{T}$ - indicator of the development of traditional factors of economic development; $\mathrm{P}$ - indicator of the development of postindustrial factors; $\mathrm{R}$ - indicator of the resistance to external financial and economic shocks Source: Authors.

The indicators for conducting cluster analysis were selected according to three groups of factors of economic development of the countries:

- Traditional factors $(\mathrm{T})$ of economic development of the countries, which are the basis of their development and competitive advantages; 
- Post-industrial (P) factors of economic development. These factors represent the development of the main resource of the post-industrial economy - a highly skilled labor force capable of developing and implementing innovations, as well as the developing and exporting of environmentally safe products, competitive in international markets. The group of post-industrial factors reflects the effectiveness of the use and development of information resources in the countries, as well as countries' ability to achieve a high level of environmental performance;

- The factors of the resistance $(\mathrm{R})$ of the countries to external financial and economic shocks and crises. These indicators include indicators of the development of the macroeconomic environment, the financial market, the efficiency of markets for goods and labor, etc.

To the group of the indicators, which reflect traditional factors of economic development of the countries we have included the following:

Institutions. This indicator is extremely important for realization of competitive advantages of the enterprises in a certain country, as the development of institutions characterizes the quality of legal and administrative environment in which agents operate and interact. At the same time institutions determine the country's attractiveness from the point of view of investors and trading partners;

Infrastructure. This indicator reflects the ability of the countries to create favourable conditions for integration of national markets, as well as their effective interaction with markets of other states and international markets. A welldeveloped infrastructure characterizes the country's ability to reduce the gap between poor and rich areas by ensuring the access of the different income groups to goods and services;

Health and primary education. Human labour has always been one of the main factors of economic growth, therefore, the quality of health and primary education provides a country with human capital, and its higher quality is determined by another indicator - the quality of vocational training. It should be noted that health and primary education reflect the primary conditions for the development of goods and services;

Higher education and training. This indicator, as well as the previous one, characterizes the international competitive advantages of the countries from the point of view of their availability of skilled labour and reflects, not only the minimum skills, but the quality of the high training, which is necessary to produce medium and high-tech goods and services.

To the group of indicators, which reflect the development of the post-industrials factors of economic development of the countries, there were included the indicators as follows:

Environmental Performance Index (EPI). This indicator directly reflects the effectiveness of all environmental and economic measures and the results of implementing the "green" strategies of the countries. While considering the international competitive advantages of the countries from the point of view of the achieved level of environmental friendliness of the economy, it is also necessary to analyze economic efficiency, which will allow the drawing up of a general "picture" of the availability of post-industrial competitive advantages precisely;

Technological readiness. This indicator shows the availability to absorb and implement technology in the economy and, thus, availability to increase the overall factor productivity; 
Innovations. This indicator, as well as the level of technological readiness, also indicates the competitive advantages of countries in the modern knowledge economy. Typically, the level of innovation development is related to the level of technological development, however, analysis of innovations allows us to assess the ability of the country to implement non-technological innovations, which include innovations in the administrative activity of the enterprises, organization of working conditions, means of information exchange between workers at enterprises, etc.;

Global Talent Index. This indicator reflects the international competitive advantages of the countries in terms of their ability to develop talented human capital and engage it in productive activities. The level of talent of a nation reflects the ability to develop high-tech and high-quality technologies, which increases the country's environmental development and economic growth. The competitive advantages of the firms depend considerably on the efficiency of talent-management. The integration of knowledge into the overall management system of an enterprise is an important factor in the development of the relationship between talentmanagement and the competitive advantages of the firms.

In the third group of indicators, which characterize the factors of the resistance of countries to external financial and economic shocks and crises were included:

Macroeconomic environment. Macroeconomic stability alone cannot fundamentally affect the performance of a particular economy. However, such a conclusion can be made when the macroeconomic situation in the country is stable. When the state is characterized by a large external debt, the service sector suffers from this, because in this case, the government's spending on education, health, and transport rapidly decreases. Alternatively, when inflation grows much faster than GDP, it dramatically affects the financial performance of enterprises and the prosperity of the nation as a whole. Thus, the quality of macroeconomic environment determines the country's ability to maintain its macroeconomic stability regardless of external challenges. The countries of the PIIGS group (Greece, Spain, Italy, Ireland and Portugal) were unable to maintain macro stability in terms of the global financial and economic crisis, that negatively affected, not only the balance of payments of these states, but also their overall image;

Goods market efficiency. This indicator is crucial when analyzing international competitive advantages of the countries in foreign markets. It shows the quality of goods and the ability to satisfy actual demand or to create demand for new goods, as well as the quality of the environment, in which producers interact. In particular, this indicator can reveal the quality of competition, political traditions, and the ability to adapt to the changing habits of the consumers, consumer lifestyles, population and sectoral changes in the economy. These characteristics reflect the intentions of other countries to establish trade relations with a given country;

Labour market efficiency. This indicator reflects the competitive advantages of countries in providing such terms of labour market, in which there are no difficulties moving from one sector of the economy to another one; there are incentives for working in each sector. This indicator should be attributed to this group, as it reflects the ability of countries to provide decent working conditions, even in times of crisis, and to preserve the quality of human capital;

Financial market development. This indicator reflects competitive advantages of the countries in terms of the development of the financial system. The im- 
portance of the development of an effective financial system is emphasized especially in the context of financial and economic crises. The world crisis of $2008-$ 2009 showed that, in those countries, which were unable to provide access to financial resources, the decline of investment activity was considerable;

Market size. This indicator reflects the "globality" of international competitive advantages of countries, as it contains by WEF methodology exports as a share of the country's GDP, which, according to UN Economic Commission for Europe (UNECE 2018), refers to indicators of the globalization of the economies;

Business sophistication. This indicator reflects the competitive advantages of the countries in the ability to create favorable conditions for building an effective business environment. This indicator includes the ease of starting business, the registration of property rights, investor protection, labour recruitment, construction permits, tax reporting procedures.

Dendrogram of clusters is presented in Fig. 7.

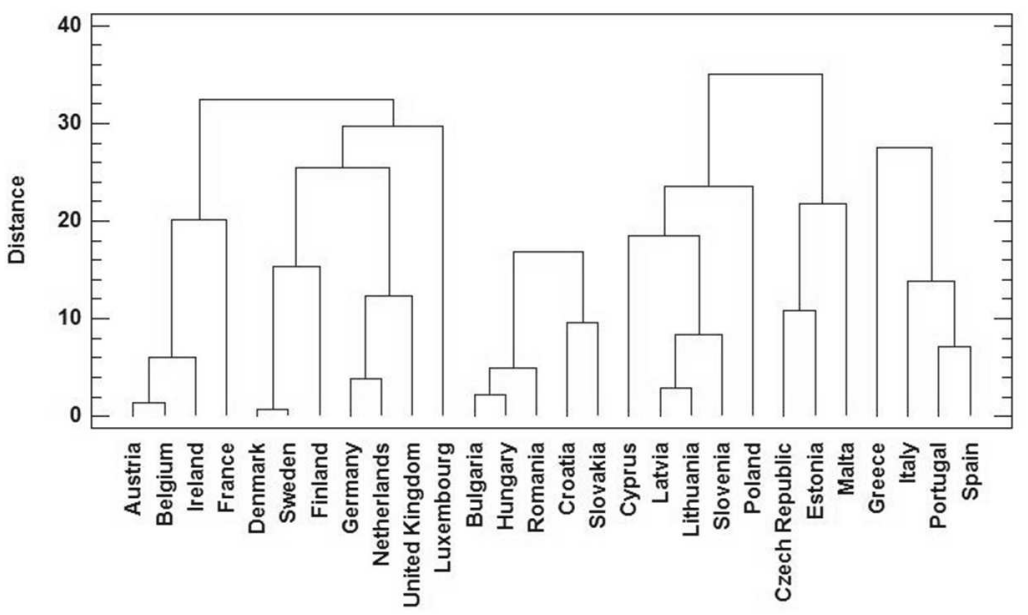

Fig. 7. Dendrogram of clusters

Source: authors.

\section{EMPIRICAL RESULTS AND DISCUSSION}

According to the Fig. 7, we have obtained four clusters:

Cluster 1: Austria, Belgium, Denmark, Finland, France, Germany, Ireland, Luxembourg, Netherlands, Sweden and United Kingdom.

Cluster 2: Bulgaria, Croatia, Hungary, Romania and Slovakia.

Cluster 3: Cyprus, Czechia, Estonia, Latvia, Lithuania, Malta, Poland and Slovenia.

Cluster 4: Greece, Italy, Portugal and Spain.

We emphasize the importance of the inclusion in cluster analysis the indicators of the outlined three groups as they provide an opportunity to obtain a relatively comprehensive understanding of why some countries have appeared in the same cluster and other countries have formed another cluster. Despite the fact there are 
commonly used indicators in assessing the strength and development of economies, like GDP, GNI or Current account as percentage of GDP, they do not reflect the influence of many factors, which have an impact on countries. As we can see from figure 8, according to the GDP only the countries of the 1st cluster are notably separated from other countries as the most developed. But not all PIGS countries (the 4 th cluster) are near each other and the countries of the 2 nd and the 3 rd clusters as well.

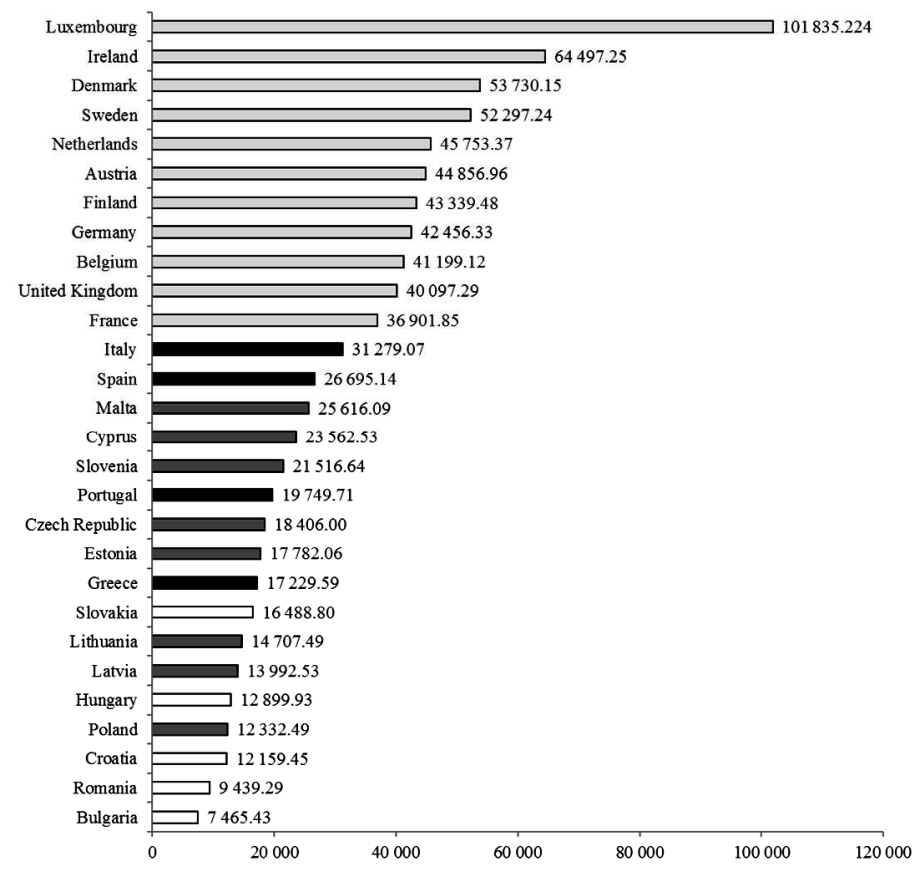

Fig. 8. Gross domestic product, US Dollars at current prices per capita, 2016

In grey color - countries of the $1^{\text {st }}$ cluster; in white color - countries of the $2^{\mathrm{d}}$ cluster; in dark grey countries of the $3^{\mathrm{d}}$ cluster; in black - countries of the $4^{\text {th }}$ cluster

Source: Authors, based on the data from UNCTAD (2016).

It is notable that almost all countries, which entered the EU in 2004, formed the 3rd cluster. Hungary and Slovakia also became members of the EU in 2004 but they continue to lag behind the other countries, which joined the EU the same year. Thus, Hungary and Slovakia formed the 2nd cluster with Bulgaria, Croatia and Romania, who were the last to join the EU.

When considering the countries of the 4th cluster we again note that many indicators should be included in order to identify the common features of EU countries. Despite our cluster analysis including various indicators, not only financial ones, the issue of financial stability is still crucial for PIIGS countries. Nevertheless, despite the general government deficit getting lower and meeting the adopted $3 \% \mathrm{lev}$ el, the value of government debt in PIIGS countries remains considerable and the highest in the EU (Fig. 9). 


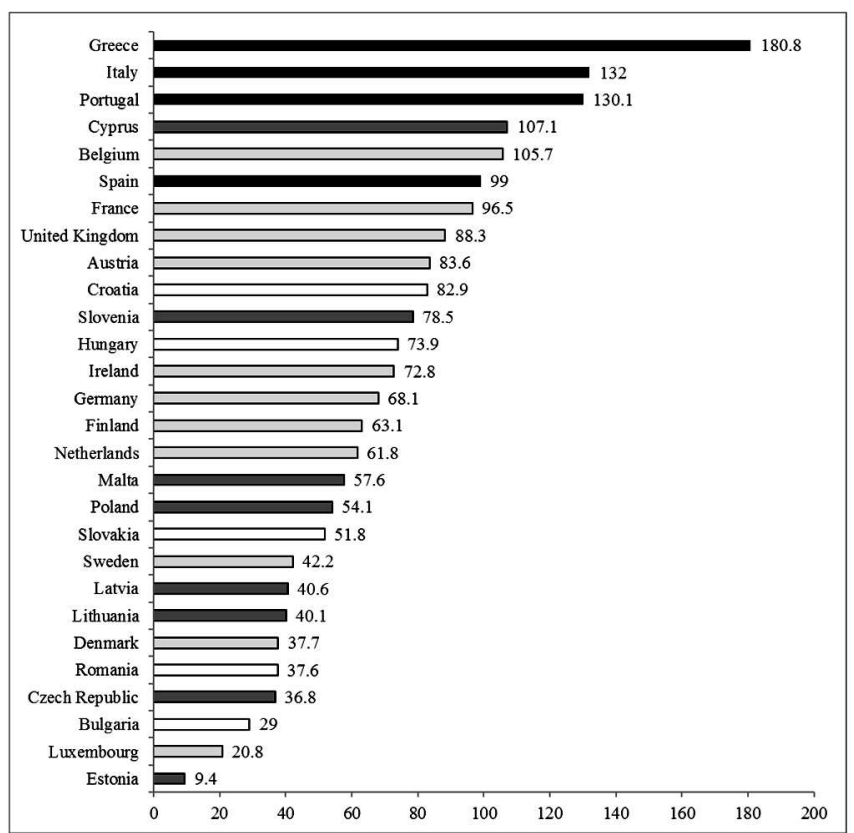

Fig. 9. General government gross debt, $\%$ of gross domestic product (GDP)

in grey color - countries of the $1^{\text {st }}$ cluster; in white color - countries of the $2^{\mathrm{d}}$ cluster; in dark grey countries of the $3^{\mathrm{d}}$ cluster; in black - countries of the $4^{\text {th }}$ cluster

Source: Authors, based on the data from European Commission (2018d).

Our analysis of the practice of application of different instruments of environmental policy by EU countries (Tab. 6) shows that the main instruments of environmental policy in the EU are subsidies, taxes and fees. It is notable that the countries of the 1st cluster are characterized by the most diverse system of environmental policy instruments. At first glance it could be explained by the highest levels of production in these countries and the bigger numbers of production firms, but the latest available statistics on the number of enterprises in the non-financial sector (Fig. 10) show that the real sector of the economy is mostly developed in Italy, France, Spain, Germany, the United Kingdom and Poland and not all of them are in the 1 st cluster.

The similar number of non-financial firms is observed in Bulgaria and Austria, Greece and Portugal. We can see similar numbers in other countries from different clusters. Thus, we can conclude, that not only the number of production firms and manufacturing explains the diversity of environmental policy instruments, but rather the level of the development of the countries. Furthermore, the analysis of the main environmental issues of the member states (Tab. 7) shows that not only developed countries suffer from air, water pollution, and other environmental problems, but other countries as well. 
GEOGRAFICKÝ ČASOPIS / GEOGRAPHICAL JOURNAL 71 (2019) 1, 15-38

Tab. 6. Application of environmental instruments in the EU

\begin{tabular}{|c|c|c|c|c|}
\hline Instruments & Cluster 1 & Cluster 2 & Cluster 3 & Cluster 4 \\
\hline & $\begin{array}{l}\text { Austria } \\
\text { Belgium } \\
\text { Denmark } \\
\text { Finland } \\
\text { France } \\
\text { Germany } \\
\text { Ireland } \\
\text { Luxembourg } \\
\text { Netherlands } \\
\text { Sweden } \\
\text { United Kingdom }\end{array}$ & $\begin{array}{l}\text { Bulgaria } \\
\text { Croatia } \\
\text { Hungary } \\
\text { Romania } \\
\text { Slovakia }\end{array}$ & $\begin{array}{l}\text { Cyprus } \\
\text { Czechia } \\
\text { Estonia } \\
\text { Latvia } \\
\text { Lithuania } \\
\text { Malta } \\
\text { Poland } \\
\text { Slovenia }\end{array}$ & $\begin{array}{l}\text { Greece } \\
\text { Italy } \\
\text { Portugal } \\
\text { Spain }\end{array}$ \\
\hline Subsidies & $\bullet$ & $\bullet$ & $\bullet$ & $\bullet$ \\
\hline Taxes and fees & $\bullet$ & $\bullet$ & $\bullet$ & $\bullet$ \\
\hline Emission trading permits & $\bullet$ & Hungary only & $\begin{array}{l}\text { Czechia } \\
\text { Estonia } \\
\text { Latvia } \\
\text { Lithuania } \\
\text { Poland Slovenia }\end{array}$ & $\bullet$ \\
\hline Environmental education & $\bullet$ & $\bullet$ & $\bullet$ & $\bullet$ \\
\hline Voluntary approaches & $\bullet$ & Slovakia only & $\begin{array}{l}\text { Czechia } \\
\text { Latvia }\end{array}$ & Italy only \\
\hline Deposit refund systems & $\begin{array}{l}\text { Denmark } \\
\text { Finland } \\
\text { Germany } \\
\text { Ireland } \\
\text { Luxembourg } \\
\text { Netherlands } \\
\text { Sweden } \\
\text { United Kingdom }\end{array}$ & $\bullet$ & $\bullet$ & $\begin{array}{l}\text { Italy } \\
\text { Spain }\end{array}$ \\
\hline National strategies & $\bullet$ & $\bullet$ & $\bullet$ & $\bullet$ \\
\hline Regulatory instruments & $\bullet$ & $\bullet$ & $\bullet$ & $\bullet$ \\
\hline
\end{tabular}

- - tools practiced for environmental regulation

Source: Authors, based on the data from European Commission, ILO (2011), United Nations (2015), OECD (2018), Stokes et al. (2001), European Environment Agency (2016). 


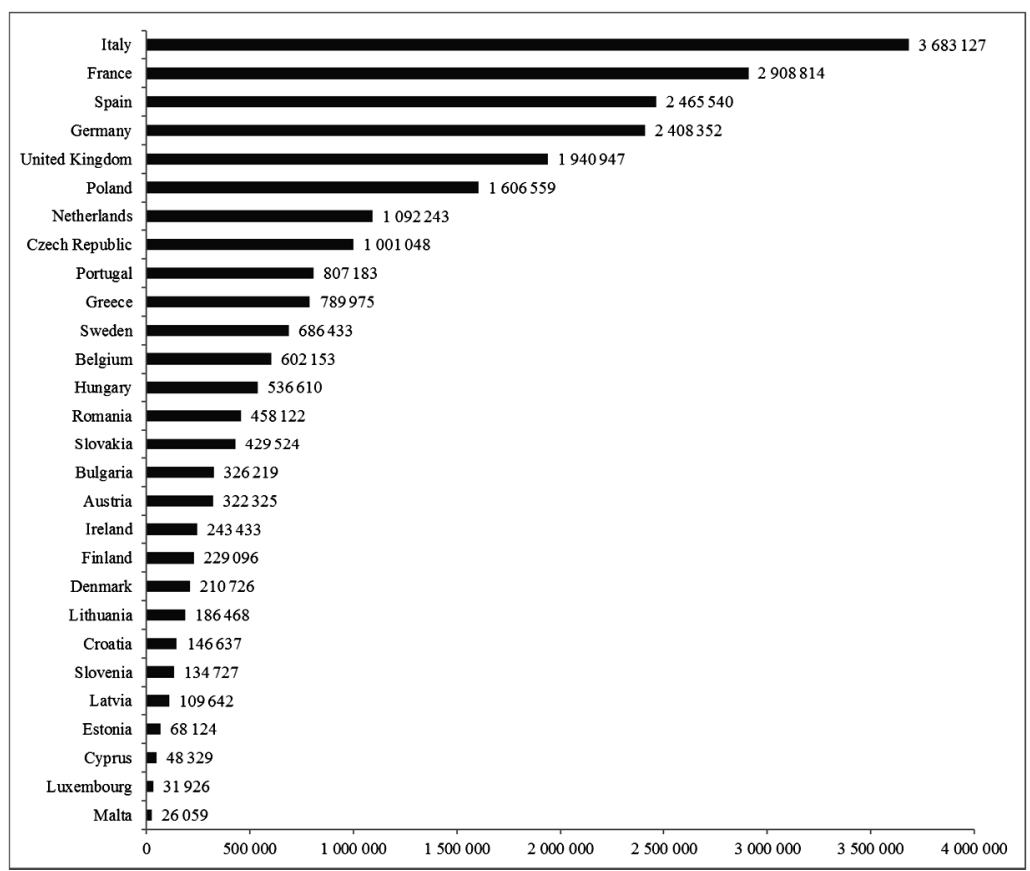

Fig. 10. Number of enterprises in the non-financial business economy by size class of employment

Source: Authors, based on the data from the European Commission, ILO (2018).

Tab. 7. The main environmental issues of the EU countries

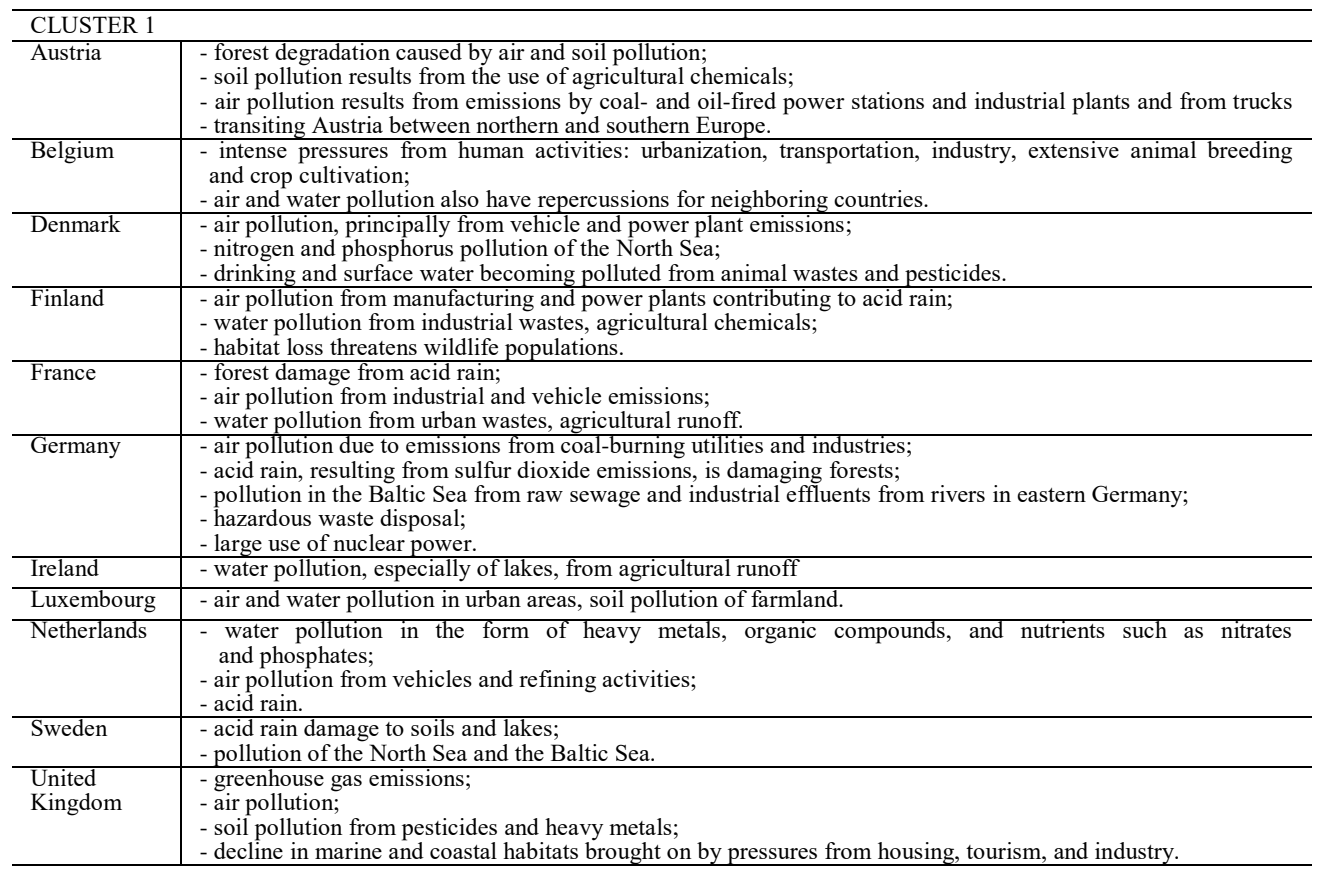




\section{Continuation of Tab. 7}

\begin{tabular}{|c|c|}
\hline \multicolumn{2}{|c|}{ CLUSTER 2} \\
\hline Bulgaria & $\begin{array}{l}\text { - air pollution from industrial emissions; } \\
\text { - rivers polluted from raw sewage, heavy metals, detergents; } \\
\text { - deforestation; } \\
\text { - forest damage from air pollution and resulting acid rain; } \\
\text { - soil contamination by heavy metals from metallurgical plants and industrial wastes. }\end{array}$ \\
\hline Croatia & $\begin{array}{l}\text { - air pollution; } \\
\text { - water pollution in the Danube River Basin. }\end{array}$ \\
\hline Hungary & $\begin{array}{l}\text { - the necessity of upgrading standards in waste management, energy efficiency, and air, soil, and water pollution } \\
\text { to meet EU requirements will require large investments. }\end{array}$ \\
\hline Romania & $\begin{array}{l}\text { - soil erosion and degradation; water pollution; } \\
\text { - air pollution in south from industrial effluents; } \\
\text { - contamination of Danube delta wetlands. }\end{array}$ \\
\hline Slovakia & $\begin{array}{l}\text { - air pollution from metallurgical plants; } \\
\text { - acid rain damaging forests. }\end{array}$ \\
\hline \multicolumn{2}{|c|}{ CLUSTER 3} \\
\hline Cyprus & $\begin{array}{l}\text { - water resource problems (no natural reservoir catchments, seasonal disparity in rainfall, sea water intrusion to } \\
\text { island's largest aquifer, increased salination in the north); } \\
\text { - water pollution from sewage and industrial wastes; } \\
\text { - coastal degradation; } \\
\text { - loss of wildlife habitats caused by urbanization. }\end{array}$ \\
\hline Czechia & $\begin{array}{l}\text { - air and water pollution in areas of northwest Bohemia and in northern Moravia around Ostrava; } \\
\text { - acid rain damaging forests. }\end{array}$ \\
\hline Estonia & $\begin{array}{l}\text { - air pollution due to sulfur dioxide from oil-shale burning power plants in northeast; } \\
\text { - coastal seawater is polluted in certain locations. }\end{array}$ \\
\hline Latvia & $\begin{array}{l}\text { - land, water and air pollution; } \\
\text { - nature protection; } \\
\text { - management of water resources and the protection of the Baltic Sea. }\end{array}$ \\
\hline Lithuania & - contamination of soil and groundwater with petroleum products and chemicals at military bases. \\
\hline Malta & $\begin{array}{l}\text { - limited natural freshwater resources; } \\
\text { - increasing reliance on desalination. }\end{array}$ \\
\hline Poland & $\begin{array}{l}\text { - air pollution remains serious because of emissions from coal-fired power plants and the resulting acid rain has } \\
\text { caused forest damage; } \\
\text { - water pollution from industrial and municipal sources is also a problem, as is disposal of hazardous wastes. }\end{array}$ \\
\hline Slovenia & $\begin{array}{l}\text { - Sava River polluted with domestic and industrial waste; } \\
\text { - pollution of coastal waters with heavy metals and toxic chemicals; } \\
\text { - forest damage from urban air pollution and resulting acid rain. }\end{array}$ \\
\hline \multicolumn{2}{|c|}{ CLUSTER 4} \\
\hline Greece & $\begin{array}{l}\text { - air pollution; } \\
\text { - water pollution. }\end{array}$ \\
\hline Italy & $\begin{array}{l}\text { - air pollution from industrial emissions such as sulfur dioxide; } \\
\text { - coastal and inland rivers polluted from industrial and agricultural effluents; } \\
\text { - acid rain damaging lakes; } \\
\text { - inadequate industrial waste treatment and disposal facilities. }\end{array}$ \\
\hline Portugal & $\begin{array}{l}\text { - soil erosion; } \\
\text { - air pollution caused by industrial and vehicle emissions; } \\
\text { - water pollution, especially in coastal areas. }\end{array}$ \\
\hline Spain & $\begin{array}{l}\text { - pollution of the Mediterranean Sea from raw sewage and effluents from the offshore production of oil and gas; } \\
\text { - water quality and quantity nationwide; } \\
\text { - air pollution; } \\
\text { - deforestation; } \\
\text { - desertification. }\end{array}$ \\
\hline
\end{tabular}

Sources: Authors, based on the data from The World Bank (2018).

All the countries of the 1st cluster joined the EU before 2004 (Austria in 1995, Belgium in 1957, Denmark 1973, Finland in 1995, France in 1957, Germany in 1957; Ireland in 1973, Luxembourg in 1957, Netherlands in 1957, Sweden in 1995 and United Kingdom in 1973), thus, earlier, then the countries in the 2nd cluster and the 3rd cluster. The countries of the 4th cluster also joined the EU before 2004 (Greece in 1981, Spain and Portugal in 1986 and Italy in 1957) but they, as we al- 
ready mentioned, have not maintained financial stability during the world crises 2008-2009, thus, their governmental spending is lower and institutional strength is weaker than in the countries of the 1 st cluster. Therefore, this could cause a lower performance in addressing environmental issues through the diverse system of environmental policy.

\section{DISCUSSION AND CONCLUSION}

Factors that define the degree of cost-effectiveness in policy implementation in the EU countries can be divided into two groups: policy factors, among which are sector organization, choice of technology, choice of policy instruments, operational efficiency and natural or policy external factors, like climate characteristics, soil conditions, landscape characteristics, administrative traditions, industry composition and others. The cost-effectiveness of environmental policy in the EU is based on the analysis of ex-ante CEAs, price of activity, use of market-based instruments, CEA as part of policy/directive and environmental expenditures. Among all the areas of environmental regulation: water, waste, climate change, biodiversity and chemicals in water and waste areas, environmental expenditures are the highest. Cost-effectiveness is mainly influenced by policy instrument choice and operational efficiency.

The analysis of environmental expenditures in the EU countries as one of the main focuses of cost-effectiveness has shown that despite increasing standards of environmental regulation, environmental protection expenditures do not place a heavy burden on the economies that is explained by the increased efficiency of sectors in responding to more stringent environmental legislation (Jantzen 2015). During $2007-2017$ the overall number of environmental infringements in the EU decreased by $47 \%$ and most of them is observed in the water and waste sector.

We have tested the hypothesis that the system of environmental instruments applied in developed EU countries is more diverse than in developing and transition economies due to the fact that developed countries have since long established laws and formal governmental structures to address their serious environmental problems. There is evidence that our hypothesis is confirmed. We used cluster analysis to obtain similar groups of the EU countries according to indicators of the development of traditional factors of economic development, post-industrial and indicators of resistance to external financial and economic shocks. Four clusters were identified. Then we analyzed the system of environmental policy instruments in each cluster. The first cluster formed Austria, Belgium, Denmark, Finland, France, Germany, Ireland, Luxembourg, Netherlands, Sweden and the United Kingdom; the second includes Bulgaria, Croatia, Hungary, Romania and Slovakia; the third cluster contains Cyprus, Czechia, Estonia, Latvia, Lithuania, Malta, Poland and Slovenia; and the fourth cluster includes Greece, Italy, Portugal and Spain. Our finding is that the degree variety of environmental policy instruments is dependent on, not only the production development and actual environmental issues, but also on other factors of development as not all the countries with a high number of production enterprises have a system of environmental policy instruments which is diverse. Only the countries of the 1st cluster are characterized by the most diverse system of environmental policy instruments. These countries joined the EU much earlier than many other member states, thus, they have a sounder institutional framework. Furthermore, we suggest that in the countries of 
the 1st cluster influential factors, which also contribute to the high degree of diversity of the system of environmental policy instruments, are social cohesion, which is pronounced in the development of voluntary approaches, environmental education approaches and innovation and knowledge-based activities, which determine the development of R\&D approaches in environmental policies. The development of these factors is led by responsible institutions and governmental bodies. We find the interplay of social, economic and institutional factors and the degree of diversity of environmental policy instruments among the EU countries is fertile ground for future research.

"This paper was written within the framework of the EDGE project, which received funding from the European Union's Horizon 2020 Research and Innovation Program under the grant agreement no. 692413."

This paper is published under the support of Visegrad Fund Programme (application number 51700846).

\section{REFERENCES}

ADAMIŠIN, P., KOTULIČ, R., MURA, L., KRAVČÁKOVÁ VOZÁROVÁ, I., VAVREK, R. (2018). Managerial approaches of environmental projects: an empirical study. Polish Journal of Management Studies, 17, 27-38. DOI: 10.17512/pjms. 2018.17.1.03.

ARBOLINO, R., CARLUCCI, F., De SIMONE, L., IOPPOLO, G., YIGITCANLAR, T. (2018). The policy diffusion of environmental performance in the European countries. Ecological Indicators, 89, 130-138. DOI: 10.1016/j.ecolind.2018.01.062.

BALANA, B., JACKSON-BLAKE, L., MARTIN-ORTEGA, J., DUNN, S. (2015). Integrated cost-effectiveness analysis of agri-environmental measures for water quality. Journal of Environmental Management, 161, 163-172. DOI: 10.1016/j.jenvman. 2015.06.035.

BALL, CH., BURT, G., De VRIES, F., MACEACHERN, E. (2017). How environmental protection agencies can promote eco-innovation: the prospect of voluntary reciprocal legitimacy. Technological Forecasting and Social Change, [Online]. Available: http:// linkinghub.elsevier.com/retrieve/pii/S0040162517315263 [accessed 11 December 2018]. DOI: 10.1016/j.techfore.2017.11.004.

BRONIEWICZ, E., ed. (2011). Environmental management in practice, [online]. Available: http://www.intechopen.com/books/environmental-management-in-practice [accessed 11 December 2018].

BURTON, R., HENN, C., LAVOIE, D., O’CONNOR, R., PERKINS, C., SWEENEY, K., GREAVES, F., FERGUSON, B., BEYNON, C., BELlONI, A., MUSTO, V., MARSDEN, J., SHERON, N. (2017). A rapid evidence review of the effectiveness and cost-effectiveness of alcohol control policies: an English perspective. The Lancet, 389, 1558-1580. DOI: 10.1016/S0140-6736(16)32420-5.

Del RÍO, P., CERDÁ, E. (2014). The policy implications of the different interpretations of the cost-effectiveness of renewable electricity support. Energy Policy, 64, 364-372. DOI: $10.1016 /$ j.enpol.2013.08.096.

EUROPEAN COMMISSION (2009). 68535-I: Scoping study on cost-effectiveness of EU environmental policy. Final Report. Denmark: European Commission, [Online]. Available: http://ec.europa.eu/environment/enveco/economics_policy/pdf/scoping study2009.pdf [accessed 23 October 2018].

EUROPEAN COMMISSION (2015). Environmental expenditures in EU industries. Brussels: European Commission, [Online]. Available: http://ec.europa.eu/environment/ enveco/economics_policy/pdf/Costs $\% 20$ of $\% 20$ environmental\%20legislation.pdf [accessed 10 October 2018]. 
EUROPEAN COMMISSION (2016a). Environmental protection expenditure in Europe EUR per capita and \% of GDP: General government. Eurostat, [Online]. Available: http://appsso.eurostat.ec.europa.eu/nui/show.do?dataset=env_ac_exp2\&lang=en [accessed 11 December 2018].

EUROPEAN COMMISSION (2016b). Environmental protection expenditure - euro per inhabitant and \% of GDP: Industry. Eurostat, [Online]. Available: http:// appsso.eurostat.ec.europa.eu/nui/submitViewTableAction.do [accessed 11 December 2018].

EUROPEAN COMMISSION (2016c). Environmental protection expenditure - euro per inhabitant and \% of GDP: Manufacturing. Eurostat, [Online]. Available: http:// appsso.eurostat.ec.europa.eu/nui/submitViewTableAction.do [accessed 11 December $2018]$

EUROPEAN COMMISSION (2018a). Statistics on environmental infringements: open directorate-general for environment infringements. European Commission, [Online]. Available: http://ec.europa.eu/environment/legal/law/statistics.htm [accessed 11 December 2018].

EUROPEAN COMMISSION (2018b). Statistics on environmental infringements: Infringements by environmental sector. European Commission, [Online]. Available: http:// ec.europa.eu/environment/legal/law/statistics.htm [accessed 11 December 2018].

EUROPEAN COMMISSION (2018c). Statistics on environmental infringements: infringements per member state, [Online]. Available: http://ec.europa.eu/environment/legal/ law/statistics.htm [accessed 11 December 2018].

EUROPEAN COMMISSION (2018d). General government gross debt. Eurostat, [Online]. Available: http://ec.europa.eu/eurostat/tgm/download.do?tab=table\&plugin=1\& language $=$ en $\&$ pcode $=$ sdg $17 \quad 40$ [accessed 10 October 2018].

EUROPEAN COMMISSION, ILO (2011). Green policies in the EU: a review, [Online]. EC-IILS JOINT DISCUSSION PAPER SERIES. International Labour Organization, European Commission. Available: http://ec.europa.eu/social/BlobServlet?docId=7246 \&langId=en [accessed 11 December 2018].

EUROPEAN COMMISSION, ILO (2018). Number of enterprises in the non-financial business economy by size class of employment. European Commission, [Online]. Available: http://ec.europa.eu/eurostat/tgm/table.do?tab=table\&init=1\&plugin=1\& language $=$ en\&pcode $=$ tin00145 [Accessed 11 December 2018].

EUROPEAN ENVIRONMENT AGENCY (2016). Current environmental policy. European Environment Agency, [Online]. Available: https://www.eea.europa.eu/ publications/92-827-4083-8/page004.html [accessed 11 December 2018].

GHISETTI, C., PONTONI, F. (2015). Investigating policy and R\&D effects on environmental innovation: a meta-analysis. Ecological Economics, 118, 57-66. DOI: 10.1016/ j.ecolecon.2015.07.009.

INSEAD (2018). The global talent competitiveness index 2018, [Online]. Fontainebleau (INSEAD). Available: https://www.insead.edu/sites/default/files/assets/dept/ globalindices/docs/GTCI-2018-report.pdf [accessed 11 December 2018].

JANTZEN, J. (2015). Environmental expenditures in EU industries, [Online]. Final Report. TME, Institute for Applied Environmental Economics, TME, Instituut voor Toegepaste Milieu-Economie. Available: http://ec.europa.eu/environment/enveco/economics policy/pdf/Costs\%20of\%20environmental\%20legislation.pdf [accessed 11 December 2018].

KHANNA, M., BROUHLE, K. (2013). Voluntary approaches to environmental protection. In Encyclopedia of energy, natural resource, and environmental economics. Amsterdam (Elsevier), pp. 226-233.

LI, Y. (2017). Voluntary disclosure and investment in environmental technology. Journal of Economic Behavior \& Organization, 133, 331-341. DOI: 10.1016/j.jebo.2016.11.002.

LIAO, Z. (2018). Environmental policy instruments, environmental innovation and the reputation of enterprises. Journal of Cleaner Production, 171, 1111-1117. DOI: 10.1016/ j.jclepro.2017.10.126. 
OECD (2018). Database on policy instruments for the environment. OECD, [Online]. Available: https://pinedatabase.oecd.org/Query 6.aspx?QryCtx $=2 \&$ isid=43bae0b0-cbb7 -4cad-b3a2-ac2ba8f68284 [accessed 11 December 2018].

OLSSON, N., JOHANSSON, U., eds. (2005). Environmental expenditure statistics industry data collection handbook. Luxembourg (Office for Official Publication of the European Communities).

PORTER, M. E., Van Der LINDE, C. (1995). Toward a new conception of the environment -competitiveness relationship. Journal of Economic Perspectives, 9(4), 97-118.

SCHWAB, K., XAVIER, S. M. (2017). Global competitiveness report 2017 - 2018, [Online]. Geneva (World Economic Forum). Available: http://www3.weforum.org/docs/ GCR2017-2018/05FullReport/TheGlobalCompetitivenessReport2017\%E2\%80\%9320 18.pdf [accessed 11 December 2018].

SHRIMALI, G., TRIVEDI, S., SRINIVASAN, S., GOEL, S., NELSON, D. (2016). Costeffective policies for reaching India's 2022 renewable targets. Renewable Energy, 93, 255-268. DOI: 10.1016/j.renene.2016.02.062.

SINGH, R. K., YABAR, H., NOZAKI, N., NIRAULA, B., MIZUNOYA, T. (2017). Comparative study of linkage between environmental policy instruments and technological innovation: case study on end-of-life vehicles technologies in Japan and EU. Waste Management, 66, 114-122. DOI: 10.1016/j.wasman.2017.04.035.

STASIAK-BETLEJEWSKA, R., POTKÁNY, M. (2015). Construction costs analysis and its importance to the economy. Procedia Economics and Finance, 34, 35-42. DOI: 10.1016/S2212-5671(15)01598-1.

STOKES, E., EDGE, A., WEST, A. (2001). Environmental education in the educational systems of the European Union, [Online]. Synthesis Report. London: London School of Economics and Political Science. Available: http://www.medies.net/ uploaded files/ ee in eu.pdf [accessed 11 December 2018].

STUCKI, T., WOERTER, M., ARVANITIS, S., PENEDER, M., RAMMER, CH. (2018). How different policy instruments affect green product innovation: a differentiated perspective. Energy Policy, 114, 245-261. DOI: 10.1016/j.enpol.2017.11.049.

TUBELO, R., RODRIGUES, L., GILLOTT, M., GONÇALVES SOARES, J. C. (2018). Cost-effective envelope optimisation for social housing in Brazil's moderate climates zones. Building and Environment, 133, 213-227. DOI: 10.1016/j.buildenv.2018.01.038.

UNCTAD (2016). Gross domestic product: total and per capita, current and constant (2010) prices, annual, 1970 - 2016, [Online]. Available: http://unctadstat.unctad.org/wds/ TableViewer/tableView.aspx [accessed 11 December 2018].

UNECE (2018). Globalization indicators by Country, Indicator and Year, [Online]. Available: http://w3.unece.org/PXWeb2015/pxweb/en/STAT/STAT 20-ME 7-GLOBIND/ ZZZ en_MENCGlobalY_r.px/?rxid=ee5dc185-b75f-48e7-82e5-60e8acc9971e [accessed 11 December 2018].

UNITED NATIONS, ed. (2015). Industrializing through trade. Economic report on Africa, 2015. Addis Ababa (United Nations Economic Commission for Africa).

WARD, J. H. (1963). Hierarchical grouping to optimize an objective function. Journal of the American Statistical Association, 58, 301, 236-244. DOI: 10.1080/ 01621459.1963 .10500845$.

WORLD BANK (2018). The world fact book. Central Intelligence Agency, [Online]. Available: https://www.cia.gov/library/publications/the-world-factbook/index.html [accessed 11 December 2018].

YAKITA, A., YAMAUCHI, H. (2011). Environmental awareness and environmental R\&D spillovers in differentiated duopoly. Research in Economics, 65(3), 137-143. DOI: 10.1016/j.rie.2010.02.003.

YALE UNIVERSITY (2018). Environmental performance index, [Online]. Yale (Yale Center for Environmental Law \& Policy, Yale University). Available: https:// epi.envirocenter.yale.edu/downloads/epi2018policymakerssummaryv01.pdf [Accessed 11 December 2018]. 
YANG, CH.-H., TSENG, Y.-H., CHEN, CH.-P. (2012). Environmental regulations, induced R\&D, and productivity: evidence from Taiwan's manufacturing industries. $R e$ source and Energy Economics, 34, 4, 514-532. DOI: 10.1016/j.reseneeco.2012.05.001.

YUSHCHENKO, A., PATEL, M. K. (2017). Cost-effectiveness of energy efficiency programs: how to better understand and improve from multiple stakeholder perspectives? Energy Policy, 108, 538-550. DOI: 10.1016/j.enpol.2017.06.015.

Marta Vovk, Boris Dziura, Martin Grešs

\section{ENVIRONMENTÁLNA STRATÉGIA EÚ: NÁHLADY NA JEJ ĎALŠ́ ROZVOJ}

Ciel'om článku je výskum nákladovej efektívnosti environmentálnej politiky v EÚ a vzt'ahu medzi rozmanitostou systému nástrojov environmentálnej politiky a hospodárskym rozvojom EÚ. Nákladová efektívnost' environmentálnej politiky v EÚ je založená na analýze CEA - Cost Effectiveness Assessment (posúdenie nákladovej efektívnosti) ex ante, cene činnosti, využívaní trhových nástrojov, CEA ako súčasti politiky/smernice a environmentálnych výdavkov. Nákladová efektívnost' je ovplyvnená predovšetkým výberom politických nástrojov a operačnou efektívnost’ou.

V súḉasnom výskume sme použili klastrovú analýzu s ciel'om identifikovat' skupiny krajín EÚ s podobnými konkurenčnými výhodami a environmentálnymi výsledkami. Klastrovanie údajov sa vykonávalo pomocou metódy Ward. Ukazovatele pre vykonávanie analýzy klastrov sme vybrali podl'a troch skupín faktorov hospodárskeho rozvoja krajín:

- tradičné faktory $(\mathrm{T})$ hospodárskeho rozvoja krajín, ktoré sú základom ich rozvoja a konkurenčných výhod;

- postindustriálne faktory (P) hospodárskeho rozvoja. Tieto faktory predstavujú vývoj hlavného zdroja postindustriálneho hospodárstva - vysokokvalifikovanú pracovnú silu schopnú rozvíjat' a zavádzat' inovácie, ako aj vývoj a export ekologicky bezpečných výrobkov, ktoré sú konkurencieschopné na medzinárodných trhoch. Skupina postindustriálnych faktorov odráža efektívnost' využívania a rozvoja informačných zdrojov v krajinách, ako aj schopnost' krajín dosiahnut' vysokú úroveň environmentálnych vlastností;

- faktory odolnosti (R) krajín voči vonkajším finančným a hospodárskym šokom a krízam. Medzi tieto ukazovatele patria ukazovatele vývoja makroekonomického prostredia, finančného trhu, efektívnosti trhov pre tovar a prácu atd'.

Získali sme nasledovné zhluky: Rakúsko, Belgicko, Dánsko, Fínsko, Francúzsko, Nemecko, Írsko, Luxembursko, Holandsko, Švédsko a Vel'ká Británia; Bulharsko, Chorvátsko, Mad'arsko, Rumunsko a Slovensko; Cyprus, Česko, Estónsko, Lotyšsko, Litva, Malta, Pol'sko a Slovinsko; a Grécko, Taliansko, Portugalsko a Španielsko.

Analýza výdavkov na životné prostredie $\mathrm{v}$ krajinách EÚ ako jeden $\mathrm{z}$ hlavných ciel'ov nákladovej efektívnosti ukázala, že napriek zvyšujúcim sa normám environmentálnej regulácie výdavky na ochranu životného prostredia nenarúšajú hospodárstvo, čo sa prejavuje zvýšenou efektívnost'ou odvetví pri reagovaní na prísnejšie environmentálne právne normy. V rokoch 2007 - 2017 sa celkový počet environmentálnych porušení v EÚ znížil o 47 \% a väčšina $\mathrm{z}$ nich sa zaznamenala $\mathrm{v}$ sektore vodného a odpadového hospodárstva.

Testovali sme hypotézu, že systém environmentálnych nástrojov používaných v rozvinutých krajinách EU je rozmanitejší ako v rozvíjajúcich sa a transformujúcich sa ekonomikách, pretože rozvinuté krajiny už dávno zaviedli zákony a formálne vládne štruktúry na riešenie svojich vážnych environmentálnych problémov. Existujú dôkazy, že naša hypotéza je potvrdená. Klastrovú analýzu sme použili na získanie podobných skupín krajín EU podl'a ukazovatel'ov vývoja tradičných faktorov hospodárskeho rozvoja, postindustriálnych ukazovatel'ov a ukazovatel'ov odolnosti voči vonkajším finančným a hospodárskym šokom. Identifikované sú štyri zoskupenia. Potom sme analyzovali systém nástrojov environmen- 
tálnej politiky v každom klastri. Prvý klaster tvorili Rakúsko, Belgicko, Dánsko, Fínsko, Francúzsko, Nemecko, Írsko, Luxembursko, Holandsko, Švédsko a Vel'ká Británia. Druhý. zahŕn̆a Bulharsko, Chorvátsko, Mad'arsko, Rumunsko a Slovensko. Tretie zoskupenie tvorili Cyprus, Česko, Estónsko, Lotyšsko, Litvu, Maltu, Pol'sko a Slovinsko a štvrtý. klaster zahŕna Grécko, Taliansko, Portugalsko a Spanielsko.

Náš záver spočíva $\mathrm{v}$ tom, že rôznorodost' nástrojov environmentálnej politiky závisí nielen od vývoja výroby a skutočných environmentálnych otázok, ale aj od iných faktorov rozvoja, pretože nie vo všetkých krajinách s vel'kým počtom výrobných podnikov je systém nástrojov environmentálnej politiky rôznorodý. Iba krajiny prvej skupiny sa vyznačujú najrozmanitejším systémom nástrojov environmentálnej politiky. Tieto krajiny vstúpili do EÚ ovel'a skôr ako mnohé iné členské štáty, a preto majú kvalitnejšie vybudovaný inštitucionálny rámec. Okrem toho konštatujeme, že v krajinách prvej skupiny existujú vplyvné faktory, ktoré prispievajú $\mathrm{k}$ vysokej miere rozmanitosti systému nástrojov environmentálnej politiky. Ide o sociálnu súdržnost', ktorá sa prejavuje vo vývoji dobrovol'ných prístupov, environmentálne vzdelávacie prístupy, inovačné a znalostné činnosti, ktoré určujú vývoj prístupov k výskumu a vývoju v politikách životného prostredia. Rozvoj týchto faktorov je vedený zodpovednými inštitúciami a vládnymi orgánmi. Na záver konštatujeme, že súhra spoločenských, hospodárskych a inštitucionálnych faktorov a miera rozmanitosti nástrojov environmentálnej politiky medzi krajinami EÚ predstavuje široký priestor pre budúci výskum. 